\title{
A Case of 40-Year-Old Male with Onodi Cell Mucocele
}

\author{
Sung-Dong Cho, Seung Heon Kang, Yuju Seo, and Hyun Jik Kim \\ Department of Otorhinolaryngology-Head and Neck Surgery, Seoul National University College of Medicine, Seoul, Korea
}

40세 남자 환자에서 발생한 오노디세포 점액낭종 1예

조성동·강승헌·서유주·김현직

서울대학교 의과대학 이비인후과학교실

\author{
Received June 22, 2019 \\ Revised August 25, 2019 \\ Accepted September 11, 2019 \\ Address for correspondence \\ Hyun Jik Kim, MD, PhD \\ Department of Otorhinolaryngology \\ Head and Neck Surgery, \\ Seoul National University Hospital, \\ Seoul National University \\ College of Medicine, 101 Daehak-ro, \\ Jongno-gu, Seoul 03080, Korea \\ Tel $+82-2-2072-2203$ \\ Fax $+82-2-745-2387$ \\ E-mail hyunjerry@snu.ac.kr
}

Sphenoethmoidal (Onodi) cells originate from the ethmoid sinus and are located at the posterior and lateral direction. The obstruction of the sinus ostium leads to the accumulation of mucous fluid and eventually leads to the formation of a mucocele. Onodi cell mucoceles can cause visual loss or disturbance due to the adjacency to the orbital apex. Here we report a case of Onodi cell mucocele with a visual field disturbance, where the patient underwent an endoscopic sinus surgery 12 days after the initial symptom. After 21 days of onset, the subjective symptom started to subside. For Onodi cell mucocele patients with visual disturbance, we recommend rapid diagnosis with computed tomography and early marsupialization of the mucocele.

Korean J Otorhinolaryngol-Head Neck Surg 2020;63(8):381-5

Key Words Ethmoid sinus · Mucocele · Optic neuritis · Visual fields.

\section{서 론}

점액낭종이란 부비동구가 폐쇄되어 점액질이 부비동 내부 에 축척되어 형성된 낭을 의미한다. 남성과 여성에서 동등한 비율로 나타나며, 30 40대에 가장 많은 유병률을 보인다. ${ }^{1)}$ 점 액낭종은 1 차성과 2 차성으로 구분한다. 1 차성 점액낭종의 경 우 점액분비 과정에서 염증반응이 생기게 되어 이 반응이 분 비관을 막게 되는 것으로 시작된다. 이후 연쇄적으로 분비샘 의 낭성 확장 및 물혹의 낭성 퇴화 과정을 일으키는 기전으로 점액낭종이 형성된다. 만성 부비동염 환자의 $41 \%$ 에서 1차성 점액낭종이 발생한다고 보고되어 있다. ${ }^{2)}$ 2차성 점액낭종은 비 강 내외의 외상 및 과거 수술력이 있는 경우, 낭포성 섬유증과 같은 분비성 낭종이 있는 경우 발생할 수 있다." 1 차성 및 2차 성 점액낭종을 치료하기 위해 조대술 혹은 수술적 절제를 시 행한다. 점액낭종은 전두동 $65 \%$, 사골동 $25 \%$, 상악동 $10 \%$ 의

This is an Open Access article distributed under the terms of the Creative Common Attribution Non-Commercial License (https://creativecommons.org/licenses/by-nc/4.0) which permits unrestricted non-commercial use, distribution, and reproduction in any medium, provided the original work is properly cited.
비율로 존재한다. ${ }^{45}$ 전두동과 사골동의 경우 안와와 인접해있 으며, 사골동과 접형동은 안와꼭지(orbital apex) 주위에 위 치하고 있어 안구 증상을 동반하는 경우가 많다.

오노디세포(sphenoethmoidal cells, Onodi cells)는 사골 동의 해부학적 변이 중 하나로, 후사골동의 측방 및 상방으 로 함기화된 공간을 일컫는다. ${ }^{6}$ 점액낭종이 오노디세포에 발 생하는 경우는 흔하지 않으며 오노디세포는 시신경이 주행 하는 시신경관의 내측에 위치하고 있어, 안구돌출, 복시, 종 물, 시력 저하 등의 증상을 동반할 수 있다. ${ }^{7)}$ 이러한 동반 증 상 중 시야 결손은 흔하지 않으며 이에 저자들은 최근 시력 저하 및 복시를 주소로 내원한 40세 남자 환자에서 시야 결 손이 동반된 오노디세포의 점액낭종 1 예를 치료하였기에 문 헌고찰과 함께 보고하는 바이다.

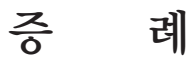

기저로 비만(체질량지수 39.8), 경계성 고혈압, 당뇨(당화혈 색소 6.8 )가 있는 환자가 1 주 전부터 발생한 좌측 시력 저하 

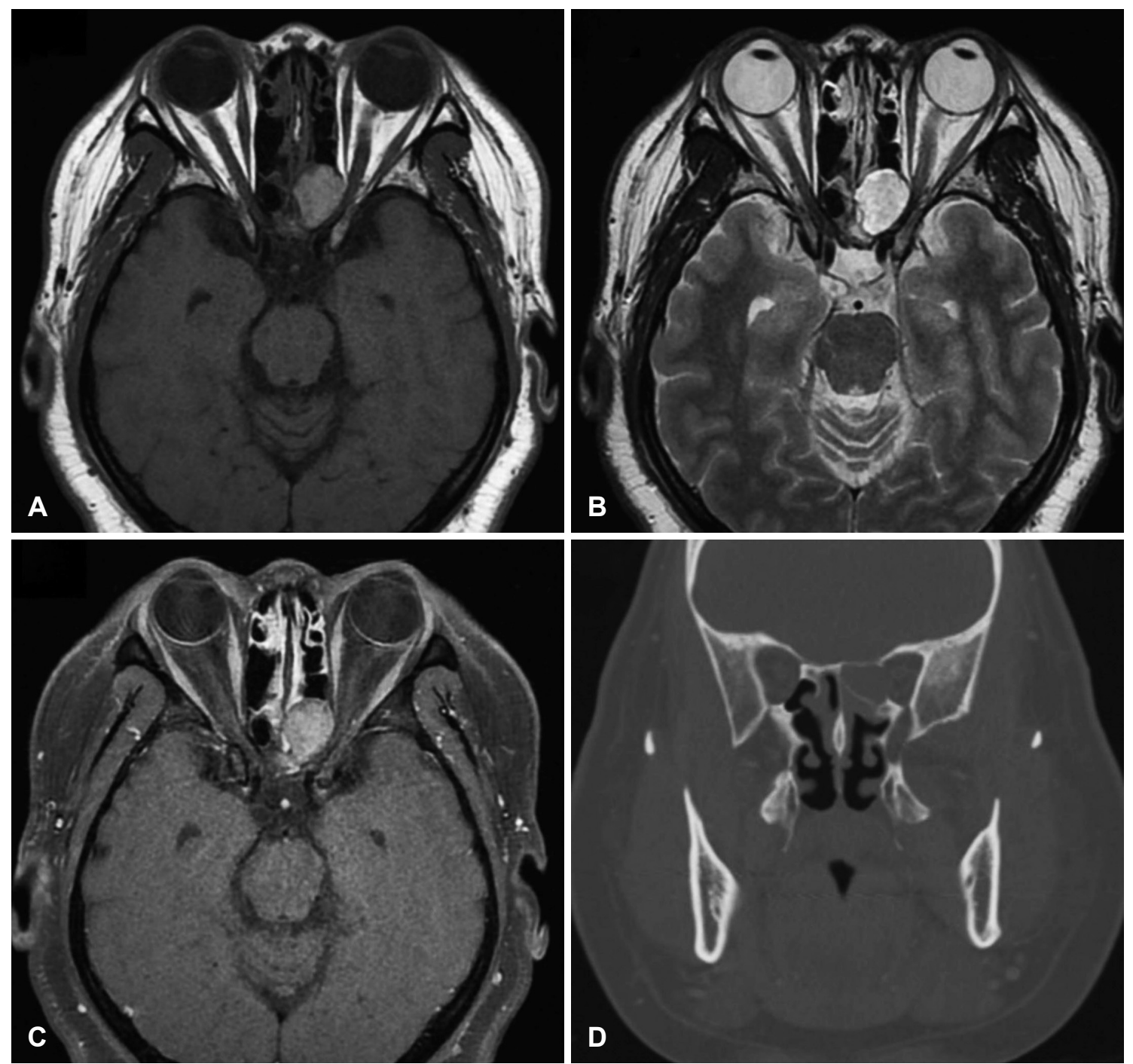

Fig. 1. A 2.1 cm mass is present at the left Onodi cell. It shows high signal at T1 (A), high signal at T2 (B), and high signal at enhanced T1 (C) weighted magnetic resonance images. It is compressing the medial wall of the optic canal $(A-C)$, but there is no intracranial involvement sign in the CT scan (D).

및 복시를 주소로 외래 내원하였다. 환자는 10년 전 양측 만성 부비동염으로 부비동 내시경 수술을 2회 받았다. 두부의 기타 수술 및 수상 과거력은 부인하였다. 시력은 정상이었으나, 갑 작스럽게 좌측 시야 중앙이 점 형태로 보이지 않고 테두리만 보이는 증상을 호소했다. 좌측 두통은 동반되었으나 어지럼 증, 실조, 사지의 위약감은 없었다. 비강 검진상 좌측으로의 비 중격만곡 및 양측 비강의 물혹 소견 외에 특이 소견은 없었다.

증상 발현 1 주 후 촬영한 자기공명영상 결과 좌측 사골동 의 약 $2.1 \mathrm{~cm}$ 크기의 T1, T2 고음영 병변이 관찰되었다. 병변 은 시신경을 압박하고 있었으며, 시신경관의 두께가 얇아져 있었다(Fig. 1). 안과 검진 결과 좌측의 시력이 0.05 로 우측 1.2 에 비해 저하되어 있었으며, 좌측 상대구심동공결손(relative afferent papillary defect) 양성, 험프리시야 검사
(Humphrey visual field)상 중심암점(central scotoma)이 있었다(Fig. 2).

증상 개선을 위해 양측 물혹을 동반한 만성 비부비동염, 좌측 오노디세포 점액낭종으로 인한 시신경병증 진단하에 부비동 내시경 수술을 통한 감압술을 계획하였다.

증상 발현 12 일 후(외래 내원 5일 후) 전신마취하 점액낭 종 조대술, 양측 부비동 내시경 수술, 비중격교정술을 시행하 였다. 오노디세포 점액낭종의 표면이 골형성(ossify)되었으며 이를 시클나이프(sickle knife)로 절개하였고 점액낭종 내부 에 시신경 등의 구조물이 없는 것을 확인 후 갈색의 점액성 분비물을 흡인하였다(Fig. 3). 좌측 시신경의 주행 경로 및 시 신경과 내경동맥 간 공간(opticocarotid recess)을 확인하였 고, 시신경관의 골결손은 없었다. 수술 과정에서 안와지방 및 


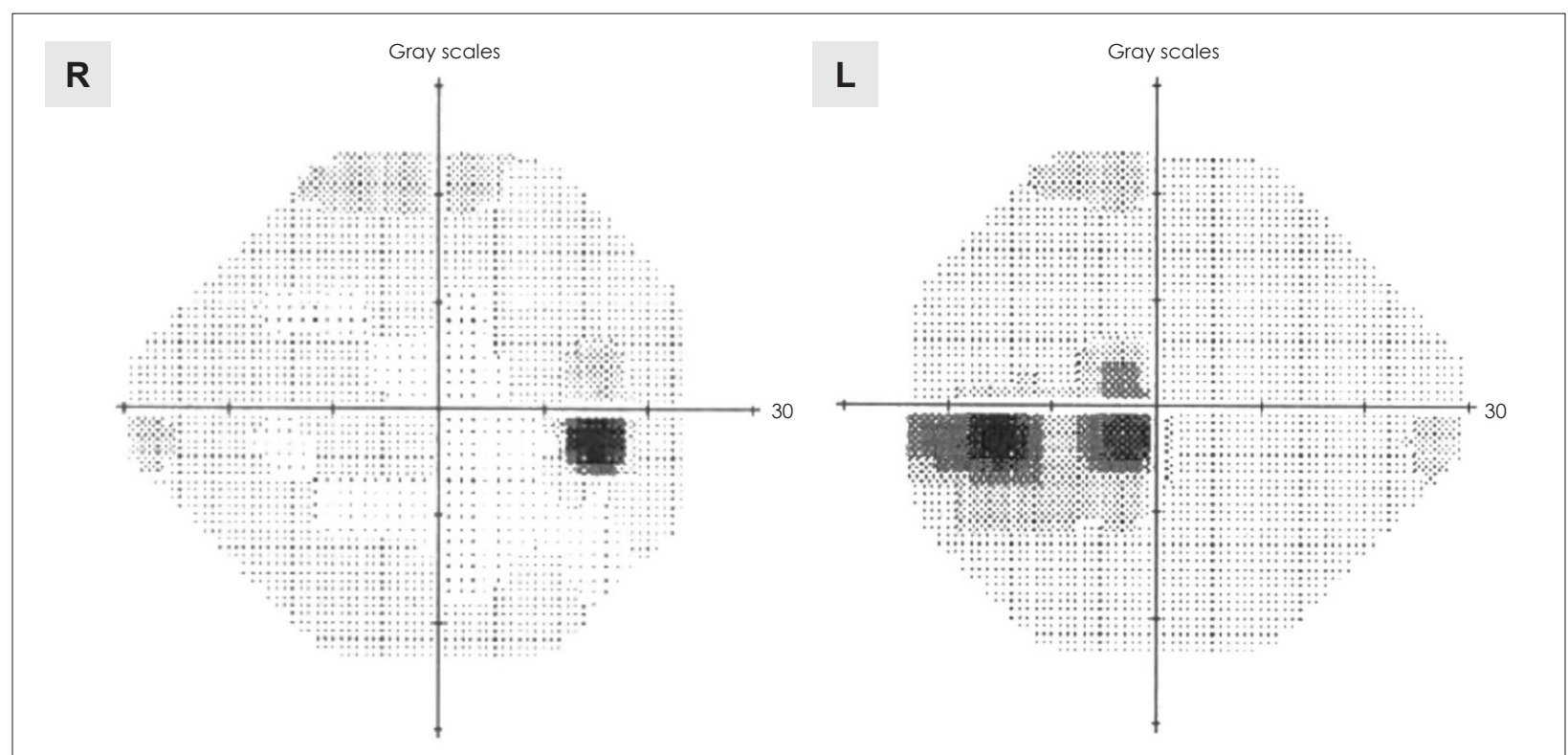

Fig. 2. On the left side of Humphrey visual field, a central scotoma is identified which is eventually a result of the compression of the optic canal.
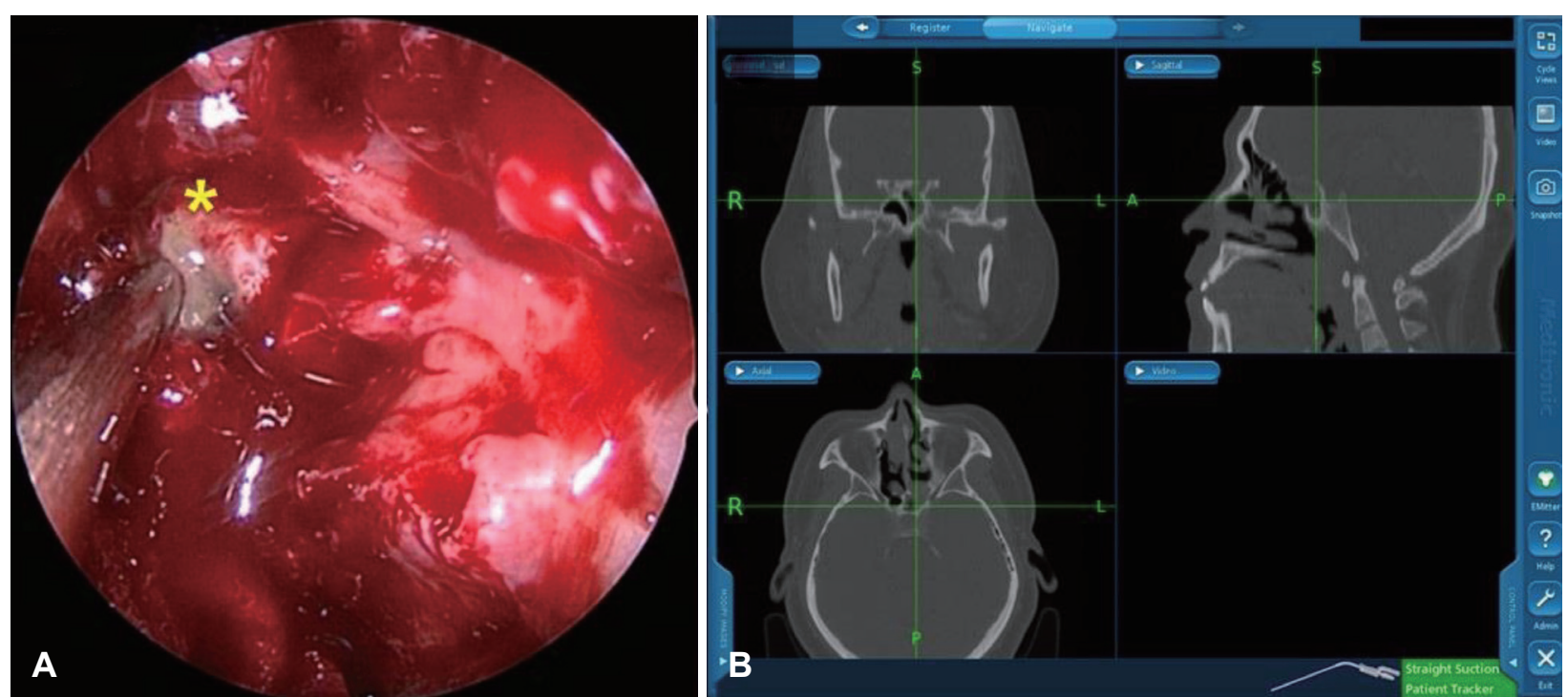

Fig. 3. Pus material coming out from the opening of the Onodi cell (A, asterisk). The navigation system assisted the surgeon to identify the Onodi cell (B).

두개저의 결손 및 손상은 없었고 코 세척 이후 패킹 시행 후 수술을 종료하였다. 수술 후 출혈, 뇌척수액비루, 안구 운동 제한 등의 급성기 합병증은 관찰되지 않았고 병동에서 하루 경과 관찰 후 퇴원하였다.

환자는 증상 발생 21일 후(수술 후 9일) 외래 내원하였다. 주관적인 좌측 중앙의 시야 결손은 회복되었다. 수술 시 시 행한 점액낭종 내측 및 외측 점막의 조직검사상 만성 염증 및 섬유화 소견을 보였고, 점액성 저류액의 배양 검사 결과
표피포도상구균(Staphylococcus epidermidis)이 동정되었 다. 안과 검진상 상대구심동공결손 양성 소견은 남아있으나 주관적 증상 호전되어 험프리시야 검사는 안과 의견에 따라 6 개월 후 시행하기로 하였다.

증상 발생 40일 후(수술 후 1개월) 외래 내원 시 시야 및 시력 모두 이상이 없었다. 수술 부위 창상은 정상 점막으로 회복되었으며 비내시경 관찰 결과 화농성 분비물은 관찰되 지 않았다. 


\section{고 찰}

점액낭종은 부비동구의 협착으로부터 기원한다. 입구가 좁아지게 되면 부비동 내부를 둘러싼 점막에서 분비되는 점 액성 분비물이 저류되어 내부의 압력이 높아지고 주위의 뼈 에 압력을 주게 된다. ${ }^{5)}$ 압력을 받은 뼈는 골흡수와 골형성 기전이 반복되어 부피가 늘어나고 주위의 구조물을 압박하 게 된다. 점액낭종은 1 차성과 2 차성으로 구분한다. 수술력 이 없거나 원인을 찾을 수 없는 경우가 1 차성, 부비동 내시경 수술 혹은 상악동근치술(Caldwell-Luc operation) 이후 발 생한 경우가 2 차성이다. 환자는 이전 부비동 내시경 수술을 2차례 받았던 환자로 2차성 점액낭종에 해당한다.

점액낭종의 부비동 내 위치에 따라 서로 다른 임상 양상을 보인다. 전두동 및 사골동에 위치하는 점액낭종의 경우 두통 (66\%), 안구 부종(22\%), 코막힘(16\%), 안면 부종(16\%)의 증상이 발현된다. 접형동에 발생할 경우에는 두통 $(89 \%)$, 시력 저하 (57\%), 안구 운동 저하(56\%), 안구돌출(25\%)의 증상이 나타난 다. ${ }^{8)}$ 전두동 및 사골동과 비교하였을 때 접형동에 점액낭종이 있을 경우 시력 저하 증상의 발생률이 상대적으로 높았다.

환자는 시야 결손을 호소하여 안과 진료 과정에서 상대구 심동공결손 및 험프리시야계를 이용한 시야측정 검사를 받 았다. 상대구심동공결손 양성은 불빛반사가 양측에서 차이 를 보이는 경우를 말하며 양성인 경우 구심성(afferent) 신경 의 비대칭적 병변 혹은 장애를 의미한다. 험프리시야계는 정 적시야를 측정하기 위한 방법으로 재현성이 높고 검사자에 따른 영향이 적어 흔히 사용된다. ${ }^{9}$ 점액낭종으로 인한 시야 결손을 진단하는 과정에서 위와 같은 정량적 계측을 고려해 야 한다.

비내접근 내시경 조대술이 점액낭종의 수술적 표준치료이 다. $\mathrm{Har}-\mathrm{El}^{10)}$ 이 1988 2000년까지 시행한 108건의 점액낭종 조대술의 분석 결과에 따르면 $83.3 \%$ 의 경우에서 점액낭종의 안와 내 침범 소견이 있었으나 주로 안와 돌출 및 안구 탈출 등의 증상을 호소하였다. 시력 저하의 증상은 적었으며 부비 동염은 증상 발현의 요인이 아니었다. 해부학적 위치별로는 전두동 60 65\%, 사골동 20 30\%, 상악동 6 10\%, 접형동 2 11\%의 비율로 존재했다.

Yumoto 등에 따르면 증상 발현 후 수술의 시점은 최소 1 일부터 최대 2 달까지 분포했다. 환자가 증상 발현 2개월 후 수술을 받았을 때 0.1이던 시력이 1.3으로 좋아진 경우도 있 었던 반면, 증상 발현 3일 후 조대술을 시행했을 때 환자 시 력이 빛인지(light perception) 수준에서 머물러 있는 경우도 있었다. ${ }^{11,12)} \mathrm{LOO}$ 등 $^{7)}$ 에 따르면 시력 저하 발생 2 9일된 환자 의 수술적 배농에도 불구하고 시력이 빛인지만 되었던 환자
들도 있었다. Moriyama 등 ${ }^{13)}$ 에 의하면 증상 발현으로부터 1 개월 이상 지난 경우 회복 가능성이 낮았으며, 실명인 경우라 도 24 시간 내에 수술을 받는다면 증상이 호전되는 경향을 보인다. 본 증례는 증상 발현 후 12 일 이후 조대술을 시행받 았던 환자로 수술 전과 비교하여 증상이 호전된 환자다. 예 후를 예측하기 어려운 경우에는 빠른 수술적 개입이 필요하 므로, 향후 수술 계획 시에는 이를 염두에 두어야 한다.

기존의 연구를 종합하면 접형동에 존재하는 점액낭종의 경우 시력 저하를 호소할 수 있지만 사골동에 존재하는 점액 낭종의 경우 시야장애 증상 발현율이 적다. 특히 후사골동이 측방 및 상방으로 함기화되어 있는 오노디세포에 존재하며 시력 저하를 동반하는 사례는 Toh와 Lee ${ }^{4)}$, Yumoto 등 ${ }^{12)}$ 이 보고한 바가 있으나, 흔하지는 않다.,12) 오노디세포는 시신경 이 주행하는 시신경관의 내측에 위치하며 정상인에서 8 14\%의 비율로 존재하기 때문에 부비동 내시경 수술 시 해 부학적 위치를 인지하고 있어야 하며 시신경 손상을 방지하 기 위해 술 전 반드시 숙지해야 한다. ${ }^{14)}$

점액낭종에서 흔히 동정되는 혐기성 군주는 펩토연쇄상구 균(61\%), 프레보텔라(42\%)이고, 호기성 군주는 황색포도구 균(17\%), 사슬알균(17\%)이다. ${ }^{15)}$ 본 증례에서는 표피포도상구 균이 동정되었다. 수술 과정에서 무균 면봉이 최대한 비강과 전사골동에 접촉하지 않도록 오노디세포로 접근하였으나, 비강이 좁아 채취 과정에서 일부 비강 점액 및 혈액이 혼합 되었다. 환자에서 동정된 표피포도상구균이 비강 내 공생균 (commensal bacteria) 중 하나이기에, 채취 과정이 무균적 (aseptic)이지 않다면 병원체(pathogen)로 간주하기에는 어 려움이 있다.

본 증례는 오노디세포에 발생한 2차성 점액낭종의 증례이 며, 흔히 발생하는 위치가 아닌 점, 안구돌출뿐만이 아닌 시 야 결손이 동반된다는 점에서 기존의 보고들과는 차이점을 보인다. 시야 변화가 있는 환자에서 부비강의 전산단층촬영을 통해 점액낭종의 유무 및 해부학적 위치를 진단하고 시야 및 시력의 개선을 위한 빠른 수술적 치료를 권장하는 바이다.

\section{Acknowledgments}

None.

\section{Author Contribution}

Conceptualization: Hyun Jik Kim. Data curation: Seung Heon Kang. Formal analysis: Yuju Seo. Methodology: Yuju Seo. Project administration: Hyun Jik Kim. Visualization: Seung Heon Kang. Writing — original draft: Sung-Dong Cho. Writing—review \& editing: Hyun Jik Kim.

\section{ORCID}

Hyun Jik Kim https://orcid.org/0000-0001-8631-928X 


\section{REFERENCES}

1) Voegels RL, Balbani AP, Santos Júnior RC, Butugan O. Frontoethmoidal mucocele with intracranial extension: A case report. Ear Nose Throat J 1998;77(2):117-20.

2) Chaiyasate $S$, Fooanant $S$, Navacharoen $N$, Roongrotwattanasiri $K$, Tantilipikorn P, Patumanond J. The complications of sinusitis in a tertiary care hospital: Types, patient characteristics, and outcomes. Int J Otolaryngol 2015;2015:709302.

3) Nicollas R, Facon F, Sudre-Levillain I, Forman C, Roman S, Triglia JM. Pediatric paranasal sinus mucoceles: Etiologic factors, management and outcome. Int J Pediatr Otorhinolaryngol 2006; 70(5):905-8.

4) Toh S-T, Lee JC. Onodi cell mucocele: Rare cause of optic compressive neuropathy. Arch Otolaryngol Head Neck Surg 2007;133(11):1153-6.

5) Capra GG, Carbone PN, Mullin DP. Paranasal sinus mucocele. Head Neck Pathol 2012;6(3):369-72.

6) Driben JS, Bolger WE, Robles HA, Cable B, Zinreich SJ. The reliability of computerized tomographic detection of the Onodi (sphenoethmoid) cell. Am J Rhinol 1998;12(2):105-11.

7) Loo JL, Looi AL, Seah LL. Visual outcomes in patients with paranasal mucoceles. Ophthalmic Plast Reconstr Surg 2009; 25(2):126-9.

8) Di Girolamo S, Cannizzaro P, Picciotti P, Nardi C. Ophthalmoplegia and ptosis as onset symptoms of an isolated primary mucocele of the sphenoid sinus. J Oral Maxillofac Surg 2002;60(12):1500-2.

9) Beck RW, Bergstrom TJ, Lichter PR. A clinical comparison of visual field testing with a new automated perimeter, the Humphrey Field Analyzer, and the Goldmann perimeter. Ophthalmology 1985;92(1):77-82.

10) Har-El G. Endoscopic management of 108 sinus mucoceles. Laryngoscope 2001;111(12):2131-4.

11) Wu W, Sun MT, Cannon PS, Jianbo S, Selva D. Recovery of visual function in a patient with an Onodi cell mucocele compressive optic neuropathy who had a 5 -week interval between onset and surgical intervention: A case report. J Ophthalmol 2010;2010: 483056.

12) Yumoto E, Hyodo M, Kawakita S, Aibara R. Effect of sinus surgery on visual disturbance caused by spheno-ethmoid mucoceles. Am J Rhinol 1997;11(5):337-43.

13) Moriyama H, Hesaka H, Tachibana T, Honda Y. Mucoceles of ethmoid and sphenoid sinus with visual disturbance. Arch Otolaryngol Head Neck Surg 1992;118(2):142-6.

14) Jones NS, Strobl A, Holland I. A study of the CT findings in 100 patients with rhinosinusitis and 100 controls. Clin Otolaryngol Allied Sci 1997;22(1):47-51.

15) Kshar A, Patil A, Umarji H, Kadam S. Mucopyocele of the maxillary sinus. Dent Res J (Isfahan) 2014;11(1):119-23. 